\title{
The Exploration and Practice of the Teaching Reform for 3D Design Technology
}

\author{
Junsheng Jiang* \\ Office of Undergraduate Academic Affairs, \\ Weifang University, \\ Weifang, Shandong, China \\ 163jsjiang@163.com
}

\author{
Yun Liu, Shanshan Guo \\ Electromechanical and vehicle department \\ Weifang University, \\ Weifang, Shandong, China
}

\begin{abstract}
To enhance the effect of classroom teaching and improve the teaching methods, three dimensional design technology is reformed from the following aspects: teaching method, teaching mode and assessment system. Through the application of multimedia assisted teaching, network teaching, discussion teaching method, case teaching method, independent study and other methods, the mutual trust and communication be tween te achers and students are enhanced, and the positive and practical ability of students are greatly improved.
\end{abstract}

Keywords-Teaching content; teaching method reform; webbased learning; assessment method

\section{INTRODUCTION}

Science and technology are catch-all term that refers to any activity have been developed rapidly, especially the application of multimedia technology and Internet technology, to some extent, the former education mode, teaching method, teaching idea and teaching means are not suitable to cultivating professional talents. [1].In order to promote sustained, healthy and rapid development of vehicle engineering, threedimensional design technology has been reformed for highquality applied talents. Three-dimensional design is not static, but dynamic. With the application of new automotive technology, digital design technology also develops. Therefore, the advanced and applicability of theoretical content should be paid attention in theory teaching [2] In light of the knowledge, ability and quality needed for the actual task of automobile design in automobile enterprises, combining the characteristics of the students in the school and taking into account the needs of the future development of the students, combining the professional training objectives and the characteristics of the curriculum, the teaching outline is formulated[3], and the task and purpose of the course, the class and nature of the course, the credits and the time of learning are clearly defined. First class, teaching materials and reference books, and prepare teaching plans, teaching plans and lecture notes according to the syllabus. Adjust the teaching order, delete duplicate contents, over old contents, and modify more advanced and difficult contents. We should strengthen curriculum[4], three dimensional basic technology is taken as the guidance, innovative design as the carrier, the principle of learning to apply to meet the requirements of modern higher education. The specific methods of reform are as follows: (i) the multifaceted teaching methods. (ii) $3+\mathrm{X}$ teaching mode. (iii)

Education and teaching reform project of Weifang University (Grant No. 2016XJ018). tailor-made assessment system.

\section{THE EXPLORATION OF MULTIFACETED TEACHING METHODS BASED ON REALITY}

Focusing on the teaching objectives of automobile design technology and the current situation of juniors, a variety of teaching methods are adopted to maintain the integrity of the Specifications. The structure is shown in Fig.1.

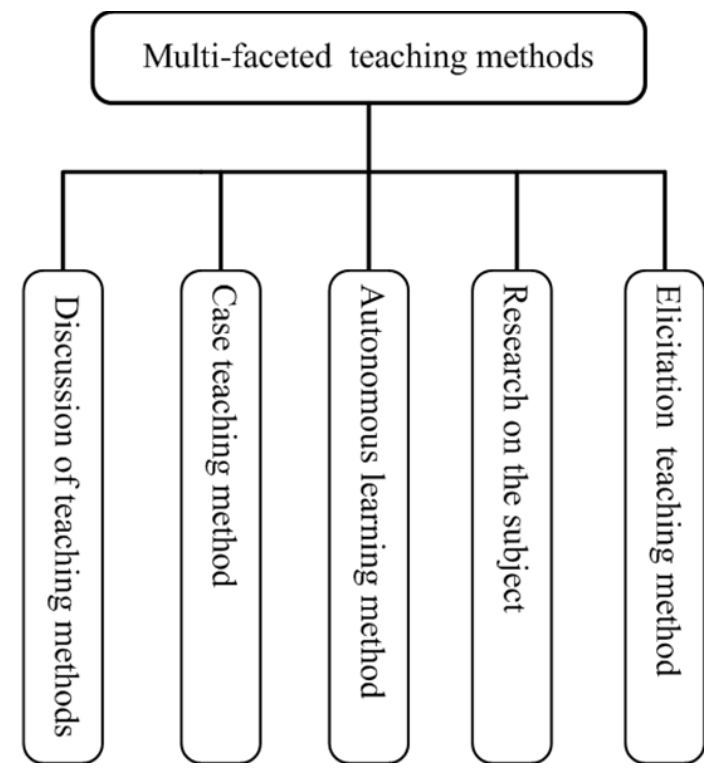

Fig. 1. The structure of the multifaceted teaching methods

\section{A. Discussion of teaching methods}

For the easily accepted sections, group design "task" teaching encourages students use the existing methods to explore the answer actively, discuss deeply with the group members, and present a consistent summary report. Through hands-on and discussion, students not only deepen the understanding of the course content, exercise the ability to analyze and solve problems, improve the ability of language expression, and cultivate the spirit of team cooperation. For example, in the three-dimensional design of the clutch, according to the knowledge of clutch design, the task "clutch structure" is assigned to inspire students to review the 
composition and working principle of the clutch and understand the three-dimensional design process of the clutch and expand the students' knowledge by consulting the information and discussing with each other.

\section{B. Case teaching method}

This course mainly introduces the three-dimensional design of the automobile system and the design of the twodimensional detailed drawings. Therefore, after the design of the basic ideas and methods of the professor, we need to give an example to deepen the understanding. Professional courses require students to master basic theories as well as engineering techniques. The former is the foundation of innovation and the latter is the material of innovation[5]. The memory of basic principles must be based on understanding and internalization. In the course of teaching, the students' understanding of the basic principles is deepened by the comparison of engineering cases.

\section{Autonomous learning method}

The highest level of higher education is how to teach students learning by themselves. Teachers set clear purpose, requirements and questions in the process of imparting knowledge and skills. In self-study, students should be taught in a variety of ways, from easy to difficult, from help to selftaught. In stance, students are guided to master the method of self-study, develop self-study plan, learn the tool book, network information technology, read notes and collate the useful information with others[6]. It is necessary to organize students' learning experience, improve their consciousness and enthusiasm, cultivate their self-learning ability and form a good habit of self-study.

\section{Self-taught method}

In the form of self-taught teaching method, the contents of the chapters are selected; the students should study independently after class by reading the textbook, network and other methods, carry on a wide discussion, form the research report, and summarize the report.

\section{E. Elicitation teaching method}

In order to enlighten and encourage students to think and answer questions actively by means of questioning, retrospection, delay judgment and discussion, the students' ideas are always attracted to the teachers' lectures by the methods of "heuristic" "interactive" "demonstration method" and "discovery method"[2]. In order to achieve the consistency and blending of teachers and students, students participate in teaching activities as much as possible. Teachers guide students to think, analyze and solve problems actively, and fully mobilize students' enthusiasm for learning.

\section{THE INNOVATION OF $3+\mathrm{X}$ TEACHING MODE}

The novel teaching modes shown in Fig.2 are based on "face-to-face" classroom teaching, experimental teaching and network teaching, and the $\mathrm{X}$ auxiliary teaching modes include: autonomous learning, visiting practice, social practice, scientific and technological innovation and so on.

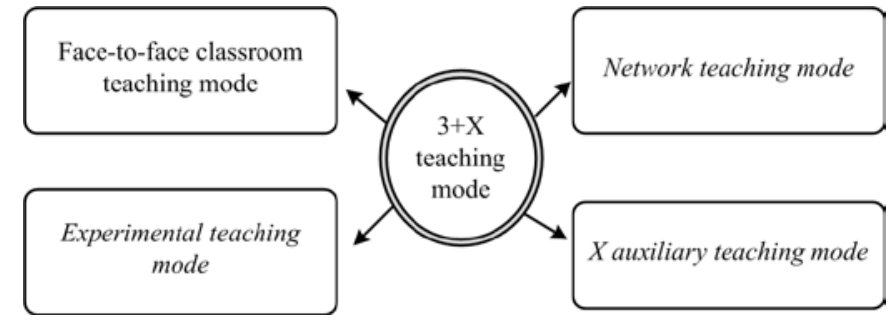

Fig. 2. The structure of the $3+X$ teaching mode

\section{A. 'Face-to-face classroom' teaching mode}

According to the purpose and nature of the course, the credit and the school hours, the first courses, the teaching materials and the reference books are clarified, and the teaching plan and lecture are written. In view of the characteristics and nature of the course content, the basic knowledge and understanding ability of the school-based students are systematically analyzed, and different teaching plans, lecture notes and multimedia courseware are designed, and various teaching methods are used flexibly.

\section{B. Experimental teaching mode}

In practice teaching, the main position of students' own practice is full played. Teachers play as the guidance to cultivate the students' logical thinking ability to analyze and solve problems, and truly exercise students' practical ability. On the basis of ensuring the theoretical teaching, we should increase the verification experiment teaching links, encourage students to do experiments in person, explore the truth voluntarily, and discover scientific phenomena. At the same time, we should increase the proportion of the practical and innovative experiments to encourage students innovate, and cultivate scientific experimental methods and rigorous working attitude through open teaching.

\section{Network teaching mode}

The network course platform of automobile design and diagnosis technology is set up. With the support of multimedia network, teaching software and classroom teaching resources are used comprehensively to provide virtual classrooms for students, including curriculum introduction, teaching syllabus, electronic teaching materials, multimedia courseware, network homework, new technology video, vehicle forum and so on. Students acquire knowledge through autonomous learning, forming a student centered, personalized and active new learning mode [3] based on network and computer.

\section{X auxiliary teaching mode}

Students visit automotive factory and participate in innovation competition by independent learning, collective teaching and other ways to contact the production line and the latest testing equipment, principles and design methods. In this way, it plays a profound way to extended the scope of students' learning, inspire the innovative consciousness, integrate theory with practice, encouraged and consolidate their professional knowledge. 


\section{THE TAILOR-MADE ASSESSMENT SYSTEM}

A. The examination and assessment method of "one volume, win or lose" are changed, and a multiaspacted assessment system is established.

This course is set in the sixth semester, the formal assessment is from the finally examination. Most students are chatting, sleeping, or even playing on the mobile phone. Therefore, it is particularly important to strengthen the assessment of the performance, attendance, homework, and small reports. In addition, the experimental links, classroom teaching, network teaching and other teaching mode shown in Fig.3. is evaluated in stages, and the specific situation is properly mastered by the teachers. In this way, the establishment of multi index and phased assessment system will help students correct their learning attitude, actively finish their homework, and attend class on time, and devote themselves to the study of the examination course.

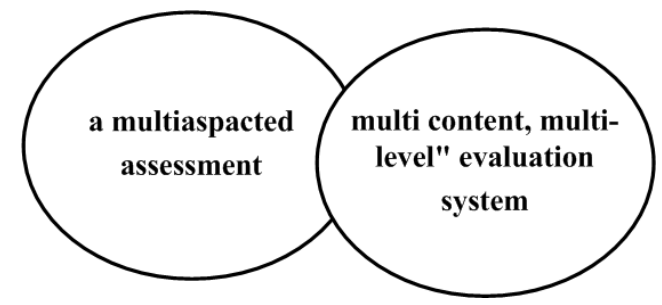

Fig. 3. The structure of tailor-made assessment system.

\section{B. A "multi content, multi-level" evaluation system}

The evaluation system of examination is widely used in universities in China for its accuracy, efficiency, adaptability and persuasion. In order to reflect the importance of the final examination and urge the students to review and prepare carefully at the end of the period, the score of the course is more than $70 \%$ of the school's general final grades. In order to make up for the heavy results and light process of examination evaluation, the communication between the evaluator and the evaluator is ignored, and the distortion of the evaluation information is easily caused. The importance and weight of the students' ordinary performance and experimental results are taken into consideration, each of which accounts for $15 \%$.

\section{CONCLUSION}

According to the training goal of applied undergraduate professional talents, the teaching reform of 3D design technology are carried out, the feasible teaching method, content, the innovation assessment method and the teaching quality are adopted. The practice has proved that the teaching reform has achieved good results. It is mainly reflected in:

(i) The students' motor design and analysis skills have been greatly enhanced, and the active exploration and research potential has been improved. The ability of autonomous learning and the effectiveness of students' participation in the classroom have been significantly enhanced. Effectively exercised engineering consciousness, the ability of integrating theory and innovative thinking are cultivated. The effect of classroom teaching has reached a new level and has played its key role in training "automobile engineers".

(ii) The teaching level of teachers has been greatly improved in all aspects. By consulting a large number of Chinese and English materials and exploring the means of teaching methods, teachers can grasp the frontier of science and technology, organize teaching effectively, and improve the level of teaching while improving the level of scientific research.

(iii) It can be popularized in similar courses of vehicle specialty. The teaching methods are similar and can be applied in similar classes.

\section{ACKNOWLEDGMENT}

This work was supported in part by education and teaching reform project of Weifang University (Grant No. 2016XJ018).

\section{REFERENCES}

[1] Ma L, Hu J, Chen Y, Liu X, Li W. Teaching Reform and Practice of the Basic Computer Course based on Flipped Classroom 2017:713-6.

[2] Zhang Y. On Study of Teaching Reform of Organic Chemistry Course in Applied Chemical Industry Technology On Study of Teaching Reform of Organic Chemistry Course in Applied Chemical Industry Technology 2017.

[3] Liu Fu fen. On Web-Based College English Teaching Reform and Practice 2011:12166624.

[4] Fang L, Ting-ting Y, Shou-gang C, Jing-duo L, Shao-gang Z. Hierarchical clustering based teaching reform courses examination data analysis approach applied in China Open University system 2014. doi:10.1109/ISCID. 2014.67.

[5] Xiao hong SHI. Under the new education idea of higher vocational colleges to explore the teaching reform 2015. doi:10.1109/ICICTA.2015.269.

[6] Tan Y, Liu X, Wang J. Teaching Reform of the Course Electromechanical Control in Independent College Based on Courses Teaching with Engineering Applied Software 2011:0-3. 